Winter 12-2011

\title{
Vaccine-preventable diseases and foreign-born populations
}

\author{
Marc Altshuler, MD \\ Thomas Jefferson University \\ Giang Nguyen, MD \\ University of Pennsylvania
}

Follow this and additional works at: https://jdc.jefferson.edu/fmfp

Part of the Family Medicine Commons, Medical Education Commons, Primary Care Commons, and the Translational Medical Research Commons

\section{Let us know how access to this document benefits you}

\section{Recommended Citation}

Altshuler, MD, Marc and Nguyen, MD, Giang, "Vaccine-preventable diseases and foreign-born populations" (2011). Department of Family \& Community Medicine Faculty Papers. Paper 25. https://jdc.jefferson.edu/fmfp/25

This Article is brought to you for free and open access by the Jefferson Digital Commons. The Jefferson Digital Commons is a service of Thomas Jefferson University's Center for Teaching and Learning (CTL). The Commons is a showcase for Jefferson books and journals, peer-reviewed scholarly publications, unique historical collections from the University archives, and teaching tools. The Jefferson Digital Commons allows researchers and interested readers anywhere in the world to learn about and keep up to date with Jefferson scholarship. This article has been accepted for inclusion in Department of Family \& Community Medicine Faculty Papers by an authorized administrator of the Jefferson Digital Commons. For more information, please contact: JeffersonDigitalCommons@jefferson.edu. 


\title{
As submitted to:
}

\section{Primary Care-Clinics in Office Practice}

\author{
And later published as:
}

Vaccine-Preventable Diseases and Foreign-Born

Populations

\section{Volume 38, Issue 4, December 2011, Pages 633-642 10.1016/j.pop.2011.07.004}

Authors:

Giang T. Nguyen, MD, MPH, MSCE - University of Pennsylvania, Philadelphia, PA Marc Altshuler, MD - Thomas Jefferson University, Philadelphia, PA

Contact Information:

GTN: nguyeng@uphs.upenn.edu

3400 Spruce St, 2 Gates/HUP, Philadelphia, PA 19104

215.615.0355(ph), 215.662.3591(fax)

MA: marc.altshuler@jefferson.edu

833 Chestnut Street, Suite 301; Philadelphia, PA 19107

215.955.5561 (ph), 215.955.8600 (fax) 
Corresponding Author: Giang T. Nguyen

Funding Support: None

Keywords: Immunization, Vaccine, Immigrant, Refugee, Minority, Adoption

Financial Disclosures/Conflicts of Interest: The authors have nothing to disclose.

\section{Synopsis}

Foreign-born individuals account for over $12 \%$ of the U.S. population, according to the most recent census data. Since many vaccine-preventable outbreaks in the U.S. have been correlated with disease importation, Congress has mandated vaccinations for numerous immigrant populations. It is essential for primary care physicians to be knowledgeable on the unique immunizationrelated needs of foreign-born individuals, to recognize some of the cultural and linguistic challenges that immigrants have accessing healthcare, and remember to use each medical encounter as an opportunity to provide necessary vaccinations.

\section{Introduction}


At the time of the 2000 Census, foreign-born individuals accounted for $11.1 \%$ of the total U.S. population. ${ }^{1}$ By 2009 , this percentage increased to $12 \%$ totaling 36.7 million foreign-born individuals in the U.S. ${ }^{2}$ The U.S. foreign-born population includes immigrants (legal permanent residents), humanitarian migrants (e.g., refugees), temporary migrants (e.g., students), and unauthorized migrants (undocumented individuals residing in the U.S.). Persons born abroad to American parents or born in Puerto Rico or other U.S. Island Areas are not considered foreign-born. ${ }^{1}$

Refugees constitute a special subset of the foreign-born population, because of the sociopolitical factors leading to their migration. From 2000 to $2009,618,090$ refugees migrated to the U.S. from over 60 different countries. The top 10 countries of origin were Cuba, the former Soviet Union, Somalia, former Yugoslavia, Burma, Iraq, Iran, Liberia, Sudan, and Vietnam. Refugees in the U.S. resettle in some regions more often than others, and the states with the largest number of resettled refugees are Florida, California, Texas, New York, and Minnesota. ${ }^{3}$

There is substantial evidence that many of the vaccine-preventable outbreaks in the U.S. have been directly related to disease importation. In 2008 , close to $90 \%$ of the measles cases in the US were either acquired overseas or imported cases, leading to 7 outbreaks and 135 infected persons. ${ }^{4}$ Even though rubella disease is less severe than measles, congenital rubella syndrome can be devastating and life-threatening. Fortunately, only two cases were reported in 
the U.S. in 2009.5 However, in one of the two cases, the individual was travelling throughout her first trimester in India and China. For these reasons, Congress has mandated vaccinations for immigrant populations in the US to decrease the public health burden from imported vaccine-preventable diseases.

As a whole, foreign-born individuals have unique immunization-related needs that can be influenced by country of origin, age of arrival to the U.S., and circumstances surrounding their migration (e.g., refugees/asylees, adoptees). Primary care physicians must be aware of these needs and be comfortable providing the appropriate services to this population.

\section{Start with the basics}

In the primary care setting, foreign-born patients may present with complicated medical and social histories, and it is important to keep in mind the standard age-appropriate preventive care recommendations that apply to all patients. Compared to their U.S. cohorts, foreign-born individuals may have more difficulty accessing healthcare due to cultural and linguistic barriers, 6,7 Foreign-born patients may be more likely to access healthcare for acute care rather than for health maintenance, so sick visits should be viewed as an opportunity to provide these important services, including vaccination. Many of these patients will not return for a separate health maintenance visit, even if the recommendation is made. In many developing countries, the concept of a health maintenance visit is largely unknown, so the idea of returning to simply 
discuss wellness issues may be viewed with skepticism, even if patients outwardly voice agreement with the follow-up plan. Vaccination should not be delayed due to mild respiratory tract infections or other acute illness, although vaccination should be deferred for moderate or severe illness. ${ }^{8}$

\section{Assessing Risk: Important Vaccine-Preventable Diseases for Foreign-Born Populations}

Knowing a patient's country of origin can help to assess the patient's level of risk for certain preventable diseases. Unfortunately, for the sake of examining the incidence of disease in these populations, immigrants are usually grouped together as a single unit, even though the incidence and prevalence of diseases differs among particular subgroups. In addition, it is also important for the primary care physician to have a general understanding of the cultural norms in these individuals, to better assess an individual's risk for disease (i.e. the risk of sexually-transmitted infections in populations with a high prevalence of sexual abuse).

Despite near total eradication of numerous vaccine-preventable diseases in the U.S., the rest of the world has not been as fortunate. In 2002, WHO (World Health Organization)

estimated that $14 \%$ ( 1.4 million deaths) of the total global mortality in children under the age of

5 years old was due to disease that could have been prevented with routine vaccination. The 
distribution of these deaths is seen in Figure 1.9

In the following sections we will focus specifically on tuberculosis, viral hepatitis, and human papillomavirus. These conditions were selected for special emphasis due to the greater burden of disease caused by these infections among immigrant populations.

\section{Infectious Disease Burden: TUBERCULOSIS}

Tuberculosis (TB) is very common in much of the world, with the continent of Africa having the largest number of high-prevalence nations. Continents with lowest rates of tuberculosis include North America, Europe, and Australia. According to the World Health Organization, the country with the highest incidence for the combined years of 2007-2008 was Swaziland in southern Africa, with an incidence of 510 per 100,000 population (compared to 2 per 100,000 in the U.S.). 10

Although immunization against TB is not commonly performed (and not routinely recommended) in the U.S., ${ }^{11}$ there are many parts of the world where for years children have been routinely given the BCG (Bacille Calmette-Guérin) vaccine to prevent TB. While the vaccine has not been shown to make a large epidemiologic impact on TB infection per se, it seems to confer some protection against serious TB disease among children, and may also protect against the development of leprosy. ${ }^{12}$ Prior vaccination with BCG can sometimes result in false positive results for the standard tuberculin skin test (TST). ${ }^{13}$ Since many 
foreign-born individuals come from areas with endemic TB, further testing is necessary to identify these high-risk individuals.

Two newer blood tests serve as alternatives to the TST and are unaffected by prior BCG vaccination: the ELISA-based QuantiFERON-TB Gold, which measures interferon gamma concentration in supernatant, and the enzymelinked immunospot (ELISpot; T-SPOT TB), which enumerates interferon-gammasecreting T cells. Both tests have better specificity than the TST, although the immunospot test appears to have higher sensitivity for detecting latent tuberculosis infection. ${ }^{13}$ Despite decreases in active TB cases for US-born individuals, the numbers of active TB cases among foreign-born individuals in the US is still relatively elevated and have remained stable over the years (Figures $2,3)$. Identification and treatment of these individuals is necessary to decrease the burden of tuberculosis disease. Unfortunately, simple, inexpensive point-ofcare tests with this level of sensitivity and specificity are still not available. ${ }^{14}$

\section{Infectious Disease Burden: HEPATITIS A}

Since the introduction of hepatitis A vaccination in 1995, cases of HAV in the U.S. have dropped $84 \% .{ }^{17}$ However, hepatitis A remains endemic in many parts of the world. High prevalence regions include sub-Saharan Africa and parts of south Asia, where it is estimated that $\geq 90 \%$ of the population have serologic evidence of infection by age 10. Intermediate prevalence occurs in Latin America, northern Africa, and the Middle East ( $\geq 50 \%$ with evidence of 
infection by age 15). ${ }^{18}$ Chronic hepatitis $A$ has not been reported, although $10-$ $20 \%$ of symptomatic patients experience a prolonged or relapsing course. ${ }^{19}$ For all patients, but particularly those who have recently traveled from high-risk regions, hepatitis A should be considered in the setting of symptoms such as abdominal pain, fatigue, nausea, anorexia, urticaria and jaundice. It is important to note, however, that infected children may be asymptomatic; only about $30 \%$ of infected children exhibit symptoms (often non-specific flu-like symptoms), and viral shedding may continue in their stools for 6 months. ${ }^{19}$

\section{Infectious Disease Burden: HEPATITIS B}

Hepatitis B is endemic in many regions of the world as well, including much of Eastern Europe, Asia, Africa, the Middle East, and the Pacific Islands (see Figure 4). Chronic hepatitis B infection can result in liver failure, cirrhosis, and hepatocellular carcinoma. Only $0.3-0.5 \%$ of the U.S. population is chronically infected with hepatitis B, but among foreign-born individuals, prevalence is 1.0 $2.6 \% .16$

People who come from countries with $\geq 2 \%$ hepatitis B prevalence are at greatest risk for both active and chronic hepatitis B infection. These individuals should be screened via Hepatitis B surface antigen testing (HBsAg) and immunized if they are not infected (unless there is documentation that there has been prior completion of the immunization series). For foreign-born persons from high-risk countries, HBsAg testing is warranted even when there is a documented 
history of immunization, because it is possible that infection could have occurred prior to immunization. In addition, testing is also recommended for U.S.-born persons who were not vaccinated as infants and whose parents were born in regions with $\geq 8 \%$ HBV endemicity (e.g., Peru, northern Brazil, Greenland, subSaharan Africa, Saudi Arabia, and much of Asia and the Pacific Islands). 16 For individuals with unknown hepatitis B immunization history, it is reasonable to consider testing for Hepatitis B surface antibody (HBsAb) before deciding to immunize; however, if the cost of serologic testing exceeds the cost of immunization, it might be more cost effective merely to vaccinate.

\section{Infectious Disease Burden: HUMAN PAPILLOMAVIRUS}

There is clear evidence in the medical literature to support the direct relationship that human papilloma virus (HPV) has on the development of cancer, including cervical, vulvar, anal, penile and oropharyngeal. HPV has been recognized as the cause of essentially all cervical cancers. ${ }^{20-22}$ Even though the number of cervical cancer cases in the US are very low, cervical cancer affects many women worldwide.23,24 HPV vaccines that are available in the US and other countries have been shown to prevent the transmission of the high-risk HPV subtypes that pose the greatest risk to the development of cervical cancer. ${ }^{24}$ For many foreign-born individuals, they are likely to be behind in cervical cancer screening. Administration of the HPV vaccine to this population at the earliest visit to the healthcare provider is essential in lowering the 
incidence of cervical cancer. It is important to remember, however, that HPV immunization does not prevent infection of all oncogenic HPV subtypes (only 16 and 18), nor does it treat infections that have already occurred prior to immunization. Therefore, Pap testing is still an essential component in the prevention of cervical cancer, regardless of HPV immunization status.

\section{Travel Medicine}

Foreign-born individuals may travel back and forth between the U.S. and their country of origin, or they may have frequent contact with other people who are from that part of the world. Consequently, it might be advisable to consider immunization against illnesses that are common in the country of origin, especially if the patient anticipates traveling there in the near future. The CDC has a comprehensive travel website (http://wwwnc.colc.gov/travel/) that can serve as an important resource. More information about travel-related immunizations can be found elsewhere in this issue.

\section{Special Considerations for Refugee Populations}

According to the United Nations Convention Relating to the Status of Refugees (Article 1A: 1951), a refugee is "someone who, owing to a wellfounded fear of being persecuted for reasons of race, religion, nationality, membership of a particular social group, or political opinion, is outside the 
country of his nationality, and is unable to or, owing to such fear, is unwilling to avail himself of the protection of that country." 25

Approximately 80,000 refugees arrive annually into the U.S., with over 2 million arrivals since 1980.26 Refugees bring a unique set of medical issues and conditions that must be addressed by the treating healthcare provider. Prior to arrival in the U.S., all refugees undergo an overseas medical examination with the purpose of identifying any diseases (i.e. active tuberculosis, leprosy) that would preclude travel to the U.S. Depending on the country of origin, vaccinations may also be provided at the time of this exam.

According to the Immigration and Nationality Act (Section 212), any individual seeking admission to the U.S. as either an incoming immigrant, or as an immigrant seeking an adjustment of status for permanent U.S. residence (green card), is ineligible for admission to the U.S. if they are unable to present the appropriate documentation of having received vaccinations against "vaccine- preventable diseases, which shall include at least the following diseases: Mumps, measles, rubella, polio, tetanus and diphtheria toxoids, pertussis, Haemophilus influenzae type B, and hepatitis B, and any other vaccinations against vaccine-preventable diseases recommended by the Advisory Committee on Immunization Practices (ACIP)." Vaccinations given overseas are considered acceptable if they have been given at the appropriate intervals and age guidelines. 
All refugees are eligible for adjustment of status after they have lived in the U.S. for 1 year. For this reason, vaccination is an essential piece in the medical care of newly arrived refugees to the US. In addition, in order for refugee children to attend school in the US, they must have either appropriate documentation of vaccinations provided overseas, or have initiated the vaccination series in the U.S. Due to the large number of vaccinations that are required for both children and adults, healthcare providers need to be very familiar with the CDC's guidelines on vaccinations, including child, adolescent, adult and catch-up schedules. As of December 14, 2009, the CDC has new criteria that will be used to decide which vaccines will be required as part of the immigration process. The criteria are as follows:

(1) The vaccine must be an age- appropriate vaccine as recommended by the ACIP for the general U.S. population, and

(2) At least one of the following:

a. The vaccine must protect against a disease that has the potential to cause an outbreak.

b. The vaccine must protect against a disease that has been eliminated in the United States or is in the process for elimination in the United States.

Any changes made by the CDC will be reflected in the CDC's Technical Instructions for Panel Physicians for Vaccinations.

(http://www.cdc.gov/immigrantrefugeehealth) The current requirements for routine vaccination during the immigration process are seen in Table 1 below. 


\section{International Adoptees and Others Receiving Vaccination Outside the United States}

Evidence of immunization prior to coming to the U.S. must be proven by written documentation, with the exception of influenza and pneumococcal polysaccharide vaccine, for which verbal history is acceptable. Adequate protection is most likely if the vaccination history closely matches the U.S. immunization schedule with regard to age of administration and immunization interval. Even with documented immunizations, however, it is possible that serologic testing may reveal inadequate protection. Repeating of immunizations according to the catch-up schedule is an appropriate option to ensure protection. 8

Vaccination/revaccination is recommended for MMR and polio. In addition, age-appropriate vaccination/revaccination is recommended for Hib, HAV, HBV (along with HBsAg testing), varicella (if lacking evidence of immunity), pneumococcal conjugate, rotavirus, HPV, and zoster. Alternatively, MMR, poliovirus and HAV immunity can be determined through serologic testing before deciding to administer these vaccines. ${ }^{8}$

Revaccination is also recommended for DTaP, but adverse local reactions are more common after the $4^{\text {th }}$ or $5^{\text {th }}$ dose. Therefore, if a severe local reaction occurs, IgG titers for tetanus and diphtheria toxins should be obtained before deciding to proceed with additional DTaP administrations (while serologic tests 
exist for tetanus/diphtheria, there are no currently available serologic tests to confirm adequate immunity against pertussis). For foreign-born children with 3 or more documented doses of DTaP prior to coming to the U.S., it is also appropriate to do tetanus/diphtheria serologic testing at initial presentation or 1 month after a booster dose. If adequate immunity is demonstrated, only standard age-appropriate immunizations would be necessary after that point. For older persons, Tdap should be administered as appropriate based on standard guidelines. ${ }^{8}$

\section{Summary}

Despite the great progress that has been made in the U.S. in the last century with vaccine-preventable diseases, significant morbidity and mortality is seen throughout the world in individuals who have not been vaccinated. As the foreign-born population in the U.S. continues to rise, primary care physicians must feel comfortable treating these individuals in a culturally and linguisticallyappropriate manner. 


\section{References}

1. US Census Bureau. USA Quickfacts from the US Census Bureau. Internet web page. Last updated 11/4/2010 2010; http://quickfacts.census.gov/afd/states/00000.html(Last accessed $3 / 17 / 2011)$.

2. U.S. Census Bureau. Foreign-Born Population of the United States Current Population Survey - March 2009. http://www. census.gov/population/www/socdemo/foreign/cps2009.htm/\# cit. 2010; accessed 4/28/2011.

3. Eckstein B. Primary care for refugees. Am Fam Physician. 201 1;83(4):429-436.

4. Grigg M, Brzezny A, Dawson J, et al. Update: Measles_United States, JanuaryJuly 2008. MMWR. 22 August 2008;57(33):893-896.

5. CDC. Summary of Notifiable Diseases--United States, 2009. MMWR. 13 May 2011; 58(53): 1-100.

6. Mohanty S, et al. Healthcare Expenditures of Immigrants in the United States: A Nationally Representative Analysis. American Journal of Public Health. August 2005; 95(8): 1431-1438.

7. Kandula NR, Kersey M, Lurie N. Assuring the Health of Immigrants: What the Leading Health Indicators Tell Us. Annu Rev Public Health. 2004; 25: 357-376.

8. CDC. General Recommendations on Immunization: Recommendations of the Advisory Committee on Immunization Practices (ACIP). MMWR. 201 1;60(RR2).

9. World Health Organization. Vaccine Preventable Diseases. Internet web page. 201 1; http://www.who.int/immunization_monitoring/diseases/en/ (Last accessed $6 / 20 / 2011)$.

10. World Health Organization. International Tuberculosis Incidence Rates. Internet web page. 2010; http://www.phac-aspc.gc.ca/tbpc-latb/itir-eng.php (Last accessed 3/17/2011).

11. CDC. The Role of BCG Vaccine in the Prevention and Control of Tuberculosis in the United States: A Joint Statement by the Advisory Council for the Elimination of Tuberculosis and the Advisory Committee on Immunization Practices MMWR. 1996:45(RR-4): 1-18.

12. CDC. Development of New Vaccines for Tuberculosis: Recommendations of the Advisory Council for the Elimination of Tuberculosis (ACET) MMWR. 1998:47(RR13): 1-6.

13. Lalvani A. Diagnosing tuberculosis infection in the 21st century: new tools to tackle an old enemy. Chest. Jun 2007;131(6): 1898-1906.

14. Wallis RS, Pai M, Menzies D, et al. Biomarkers and diagnostics for tuberculosis: progress, needs, and translation into practice. Lancet. May 29 2010;375(9729): 1920-1937.

15. CDC. Trends in Tuberculosis--United States, 2008. MMWR. March 20, 2009; 58(10);249-253. 
16. Weinbaum CM, Williams I, Mast EE, et al. Recommendations for Identification and Public Health Management of Persons with Chronic Hepatitis B Virus Infection. MMWR - Morbidity \& Mortality Weekly Report. Sep 19 2008;57(RR08): 120.

17. CDC. Hepatitis Awareness Month - special issue. MMWR - Morbidity \& Mortality Weekly Report. May 12 2006;55(18):505-528.

18. Jacobsen $\mathrm{KH}$, Wiersma ST. Hepatitis A virus seroprevalence by age and world region, 1990 and 2005. Vaccine. Sep 24 2010;28(41):6653-6657.

19. Brundage SC, Fitzpatrick AN. Hepatitis A. American Family Physician. Jun 15 2006;73(12):2162-2168.

20. Parkin DM. The global health burden of infection-associated cancers in the year 2002. International Journal of Cancer. 2006;1 18(12):3030-3044.

21. U.S. Cancer Statistics Working Group. United States Cancer Statistics: 1999-2007 Incidence and Mortality. Atlanta GA: Department of Health and Human Services, Centers for Disease Control and Prevention, and National Cancer Institute; 2010.

22. D'Souza $G$, Kreimer AR, Viscidi R, et al. Case-Control Study of Human Papillomavirus and Oropharyngeal Cancer. New England Journal of Medicine. 2007:356(19): 1944-1956.

23. W. H. O. Human Papillomavirus and Related Cancers: World Health Organization; November 152010.

24. Garland SM, Hernandez-Avila M, Wheeler CM, et al. Quadrivalent Vaccine against Human Papillomavirus to Prevent Anogenital Diseases. New England Journal of Medicine. 2007;356(19): 1928-1943.

25. United Nations for High Commissioner for Refugees (UNHCR). _Internet web page. 2010; http://www.unhcr.org/3b66c2aa10.html (last accessed 6/19/2011).

26. Anonymous. Report to Congress: Proposed Refugee Admission for Fiscal Year 201 1: U.S. Department of State, U.S. Department of Homeland Security, U.S. Department of Health and Human Services; 2010.

27. CDC. 2009 Technical Instructions for Panel Physicians for Vaccinations. Internet web page. 2010;

http://www.cdc.gov/immigrantrefugeehealth/exams/ti/panel/vaccinationpanel-technical-instructions.html (last accessed 6/24/201 1). 
Figure 1: Distribution of estimated annual deaths from vaccine-preventable diseases, $2002 .{ }^{9}$

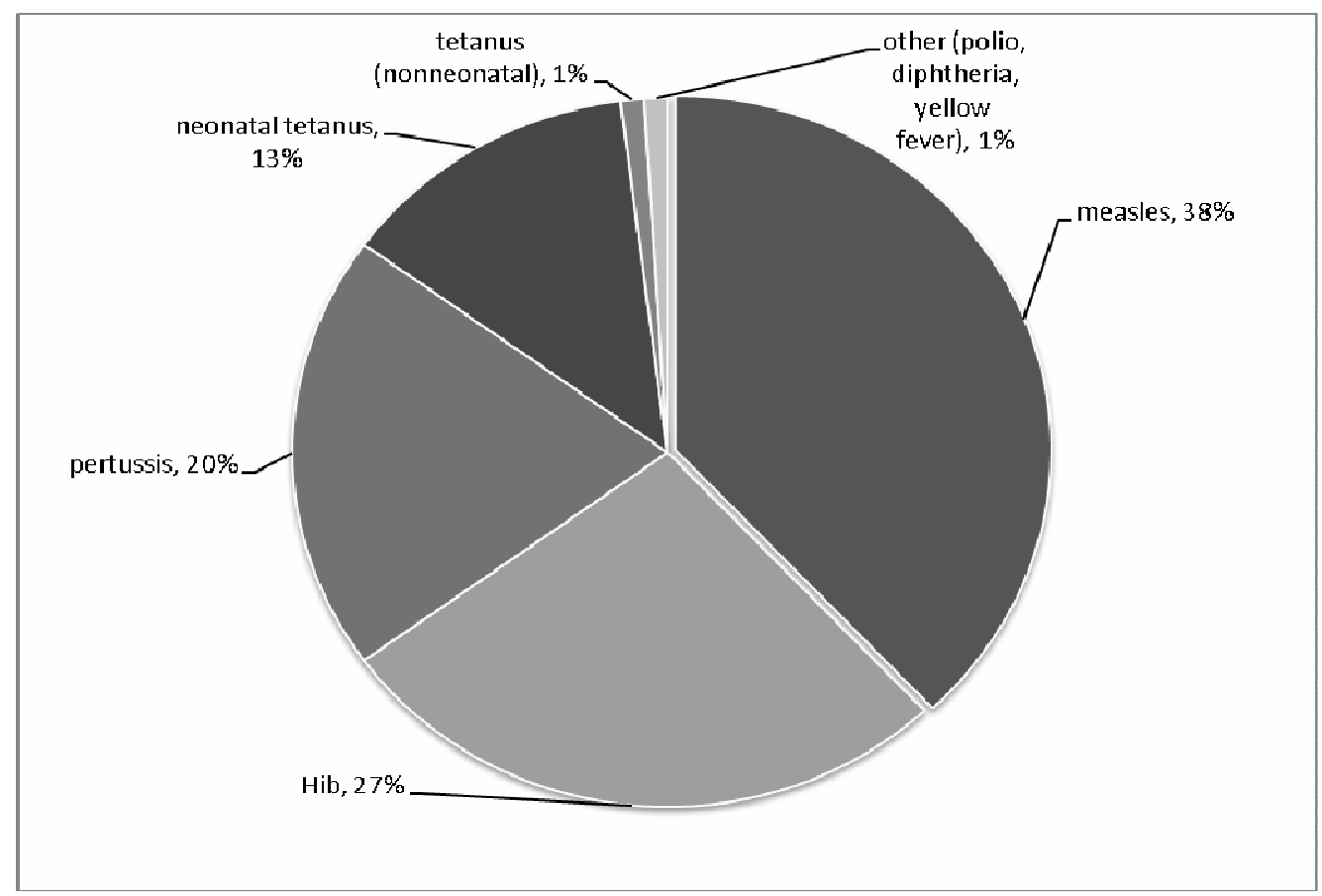


FIGURE 2: Number and rate* of tuberculosis (TB) cases among U.S.-born and foreignborn persons, by year --- United States, 1993-2010. ${ }^{15}$

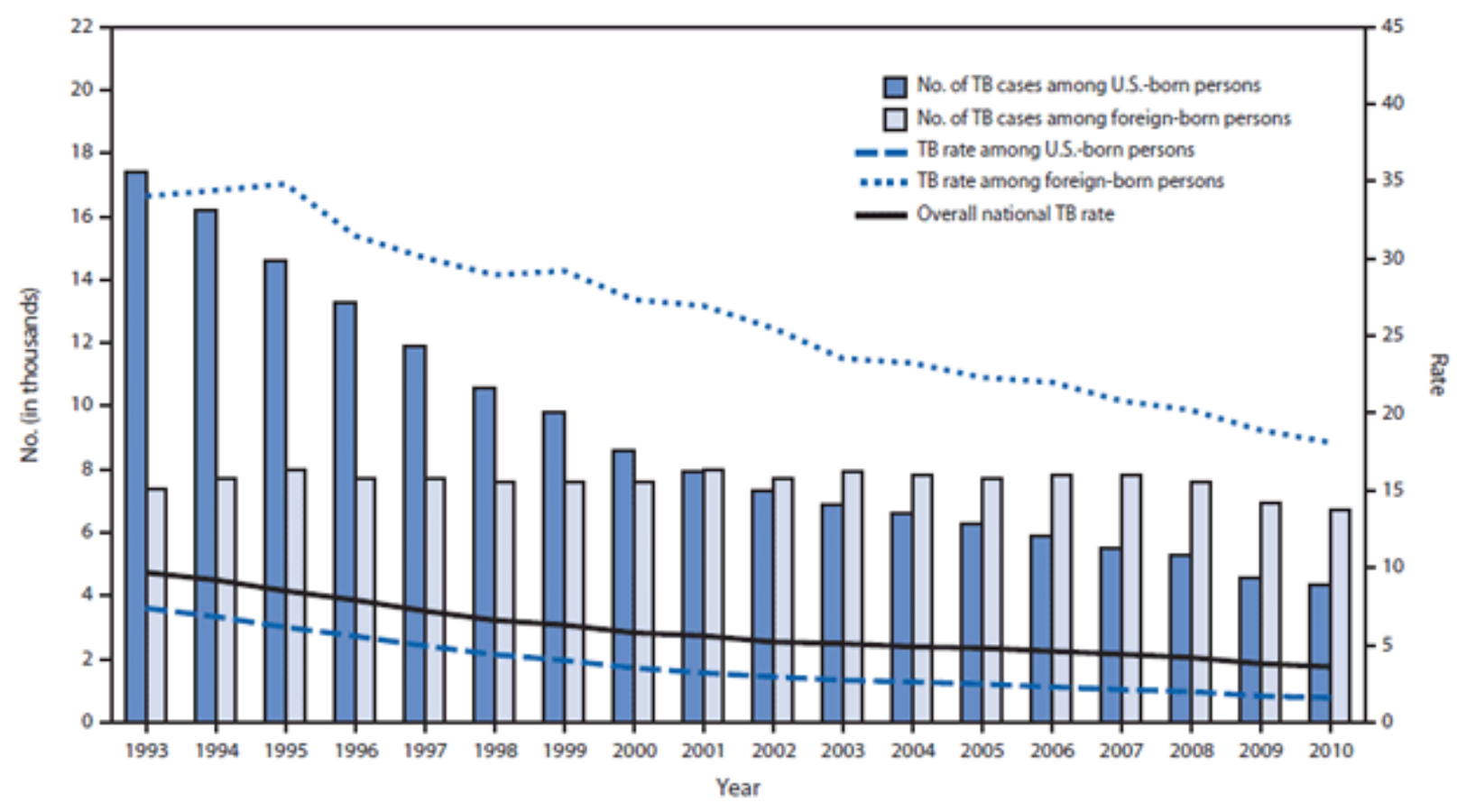

Figure 3: Number of TB cases reported among U.S. born and foreign-born individuals (1999-2009). ${ }^{5}$ 


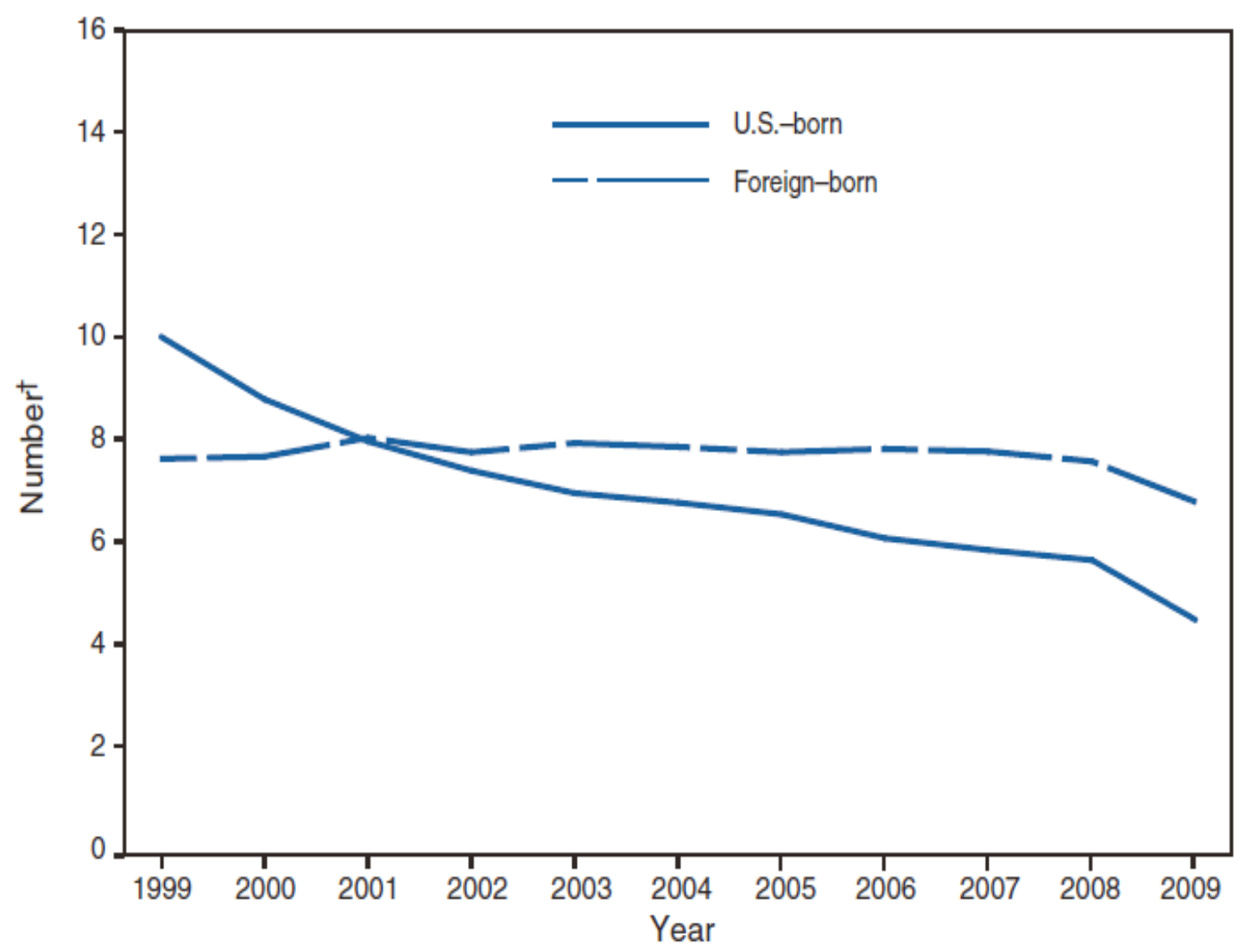

Figure 4: Geographic distribution of chronic hepatitis B virus (HBV) infection - worldwide, $2006 .{ }^{16}$ 


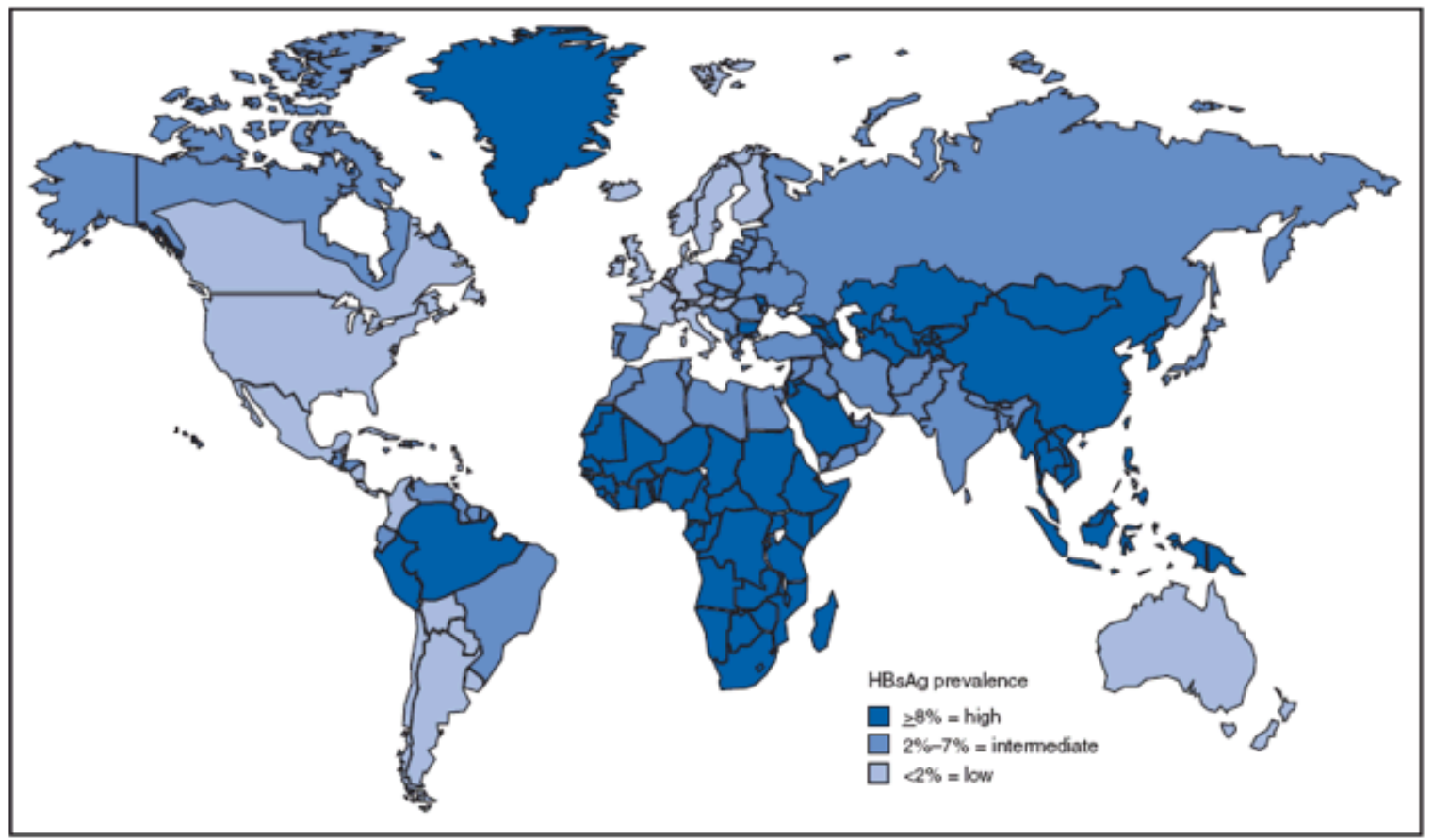

- For multiple countries, estimates of prevalence of hepatitis B surtace antigen (HBsAg), a marker of chronic HBV infection, are based on limited data and might not reflect current prevalence in countries that have implemented childhood hepatitis B vaccination. In addition, HBsAg prevalence might vary within countries by subpopulation and locality.

Source: CDC. Travelers' health; yellow book. Atlanta, GA: US Department of Health and Human Services, CDC; 2008. Available at http:/Wwwn.codc.gow' travelyellowbookch4-HepB.aspx.

Table 1: Requirements for routine vaccination of immigrants examined overseas who are not fully vaccinated or lack documentation. ${ }^{27}$ 


\begin{tabular}{|c|c|c|c|c|c|c|c|}
\hline \multirow[b]{2}{*}{ Vaccine } & \multicolumn{7}{|c|}{ Age } \\
\hline & $\begin{array}{l}\text { Birth-1 } \\
\text { Month }\end{array}$ & $\begin{array}{l}2-11 \\
\text { Months }\end{array}$ & $\begin{array}{l}12 \\
\text { Months-6 } \\
\text { Years }\end{array}$ & $\begin{array}{l}7-10 \\
\text { Years }\end{array}$ & $\begin{array}{l}11-17 \\
\text { Years }\end{array}$ & $\begin{array}{l}18-64 \\
\text { Years }\end{array}$ & $\begin{array}{l}\geq 65 \\
\text { Years }\end{array}$ \\
\hline DTP/DTaP/DT & NO & \multicolumn{2}{|c|}{ YES } & \multicolumn{4}{|c|}{ NO } \\
\hline Td/Tdap & \multicolumn{3}{|c|}{ NO } & \multicolumn{4}{|c|}{$\begin{array}{l}\text { YES, if } 7 \text { years and older (for Td); if } 10 \\
\text { years through } 64 \text { years (for Tdap- see ACIP } \\
\text { schedule); if } 65 \text { years and older (for Td) }\end{array}$} \\
\hline $\begin{array}{c}\text { Polio } \\
\text { (IPV/OPV) }\end{array}$ & NO & \multicolumn{4}{|c|}{ YES } & \multicolumn{2}{|c|}{ NO } \\
\hline $\begin{array}{l}\text { Measles, } \\
\text { Mumps, and } \\
\text { Rubella }\end{array}$ & \multicolumn{2}{|c|}{ NO } & \multicolumn{3}{|c|}{ YES, if born in 1957 or later } & \multicolumn{2}{|c|}{$\begin{array}{l}\text { NO, if born } \\
\text { before } 1957\end{array}$} \\
\hline Rotavirus & NO & $\begin{array}{c}\text { YES, if } \\
6 \text { weeks } \\
\text { to } 8 \\
\text { months }\end{array}$ & \multicolumn{5}{|c|}{ NO } \\
\hline Hib & NO & \multicolumn{2}{|c|}{$\begin{array}{l}\text { YES, if } 2 \text { months through } \\
59 \text { months }\end{array}$} & \multicolumn{4}{|c|}{ NO } \\
\hline Hepatitis A & \multicolumn{2}{|c|}{ NO } & $\begin{array}{l}\text { YES, if } 12 \\
\text { months } \\
\text { through } 23 \\
\text { months }\end{array}$ & \multicolumn{4}{|c|}{ NO } \\
\hline Hepatitis B & \multicolumn{5}{|c|}{ YES, birth through 18 years } & \multicolumn{2}{|c|}{ NO } \\
\hline $\begin{array}{l}\text { Meningococcal } \\
\text { (MCV4) }\end{array}$ & \multicolumn{4}{|c|}{ NO } & $\begin{array}{c}\text { YES, if } 11 \\
\text { years } \\
\text { through } 18 \\
\text { years }\end{array}$ & \multicolumn{2}{|c|}{ NO } \\
\hline Varicella & \multicolumn{2}{|c|}{ NO } & \multicolumn{5}{|c|}{ YES } \\
\hline Pneumococcal & NO & $\begin{array}{l}\text { YES, if } 2 \mathrm{~m} \\
59 \text { mont }\end{array}$ & $\begin{array}{l}\text { nths through } \\
\text { s(for PCV) }\end{array}$ & & NO & & $\begin{array}{l}\text { YES (for } \\
\text { PPV) }\end{array}$ \\
\hline Influenza & \multicolumn{2}{|c|}{ NO } & \multicolumn{5}{|c|}{ YES, 6 months and older (annually each flu season) } \\
\hline
\end{tabular}

$\mathrm{DTP}=$ diphtheria and tetanus toxoids and pertussis vaccine; $\mathrm{DTaP}=$ diphtheria and tetanus toxoids and acellular pertussis vaccine; DT=pediatric formulation diphtheria and tetanus toxoids; $\mathrm{Td}=$ adult formulation tetanus and diphtheria toxoids; Tdap=adolescent and adult formulation tetanus and diphtheria toxoids and acellular pertussis vaccine (Boostrix for persons 10-64 years old; Adacel for persons 11-64 years old); IPV=inactivated poliovirus vaccine (killed); OPV=oral poliovirus vaccine (live); Hib=Haemophilus influenzae type b conjugate vaccine; $\mathrm{MCV}=$ meningococcal conjugate vaccine; $\mathrm{PCV}=$ pneumococcal conjugate vaccine; $\mathrm{PPV}=$ pneumococcal polysaccharide vaccine.

Adapted from ACIP recommendations. 